\title{
LIMNOLOGICAL CONDITION AND ESTIMATION OF POTENTIAL FISH PRODUCTION OF KERINCI LAKE JAMBI, SUMATRA
}

\author{
Samuel ${ }^{1}$, Ni Komang Suryati ${ }^{1}$ and Vipen Adiansyah ${ }^{1}$ \\ ${ }^{1}$ Research Institute for Inland Fisheries, Palembang \\ Received; January 29-2015 Received in revised from June 17-2015; Accepted June 19-2015 \\ e-mail:sam_asr@yahoo.co.id
}

\begin{abstract}
Kerinci Lake is a type of tectonic lakes located in a protected forest area of National Park of Kerinci Sebelat and a source of various fish species important for local people for their daily food comsumption and income. However, few information is available on its limnological condition and fish resources. Field research observing the limnological condition and estimating the potential fish production was conducted four times in April, June, August and October 2013. The research is aimed to describe the condition of limnology to estimate the potential fish production of the lake. Limnological aspect included the physico-chemical and biological parameters, namely: temperature, water transparency, depth, substrate, conductivity, $\mathrm{pH}$, dissolved oxygen, alkalinity, ammonia, nitrate, phosphate, total phosphorus, chlorophyll-a and trophic state. Potential fish production was calculated by using the biological parameter levels of chlorophyll-a. The results show that the euphotic layer of the lake waters was still feasible for fish life. Water condition of the bottom layer was less supportable for fish life due to low dissolved oxygen content. Trophic state index (TSI) values, either measured by temporal or spatial ways, had TSI with an average of 61.75. From these indeces, the lake is classified as a lake at the high productivity level (eutrophic). Annual fish production was an average of $307 \mathrm{~kg} / \mathrm{ha} /$ year. By taking account the average of fish production and the total area of lake of around 4,200 ha, the potential fish production of Kerinci Lake is estimated about $\pm 1,287$ tons/year.
\end{abstract}

KEYWORDS: Water quality, trophic state, potential fish production, Kerinci Lake of Jambi, Sumatra

\section{INTRODUCTION}

Kerinci Lake located in Kerinci Regency of Jambi Province at the altitude of \pm 783 meters above sea level (Ministry of Environment, 2013) is one type of tectonic lakes in Indonesia. The lake has an area of \pm 4,200 hectares with a maximum depth of \pm 110 meters. The famous fish of the lake is mahseer (Tor duoronensis) and some economically important fish. The numbers of fish such as: climbing perch (Anabas testudineus), snakedheads (Channa striata), giant gouramis (Osphronemus gouramy) and marble goby (Oxyeleotris marmorata) decline as a result of damage on the catchment area of the lake (Gazam, 2013). Besides that there are also various species of freshwater fish such as: bonylip barb (Osteochilus waandersii), hampala barb (Hampala macrolepidota), common carp (Cyprinus carpio), nile tilapia (Oreochromis niloticus), silver rasbora (Rasbora argyrotaenia), the fire eel (Mastacembelus erythrotaenia), snakeskin gourami (Trichogaster pectoralis) and asian swamp eel (Monopterus albus).

Prior to 1995, the condition of the waters of lake was covered by a blooming aquatic hyacinth plant (Eichornia crassipes) to almost of the lake surface. In 1995, a number of 2,000 fingerling of grass carp (Ctenopharynggodon idella) were imported from China by the local Fisheries Department to be introduced to the lake for cleaning the waters of the lake from the hyancinth plant. Then after more than 10 years later, the waters of the lake had been returned clean $100 \%$ of the water hyacinth (Sriwijaya Post "Water Hyacinth in Lake Kerinci all gone edible fish Koan ", May 19, 2011).

After the lake water condition cleaned from aquatic hyacinth plants, some native fish species of lake (mahseer, snakeskin gourami, climbing perch, silver rasbora and others) had been rarely caught. The fact was too difficult to find the native fish in the market. The declining of some native fish species in the lake was also complained by local people inhabiting in around Kerinci Lake, especially the in habitants who work as fishermen. This scarcity of native fish caused the reducing of income of the fishermen (Kementerian Lingkungan Hidup, 2013). Declining of fish production and reducing the catches indicated the absence of external factors that negatively influence upon fishery conditions in Lake Kerinci.

Water quality condition of the lake is still good enough to support the life of some fish species. This is reflected by the fact that many fishermen do their fishing activity in the lake. However, it is needed to do an assessment of the water quality to evaluate the 
extent of the water condition in supporting the fish life and how much water capacity to produce the fish. The purpose of research in Kerinci Lake to evaluate the aspects of limnology and to estimate the potential fish production as essential information for the fish resources management in Kerinci Lake.

\section{MATERIALS AND METHODS}

Field surveys to collect data were conducted four times: in April, June, August and October 2013. Six stations for sampling and measurement of water quality were determined by considering the land use around the lake such as the existence of residential areas, agricultural areas and plantation, protected forest areas, littoral areas, the position of the inlet and outlet, as well as in the middle of the lake (Figure 1).

Measurement and water sampling were conducted with vertical stratification. The stratification was based on the results of measurements on the boundary of water transparency and depth of the lake which further stratified into several layers of water. Physico-chemical and biological parameters of lake waters were measured by using some materials, various tools and methods as outlined in Table 1. The parameters are: temperature, transparency, depth, substrate, conductivity, $\mathrm{pH}$, dissolved oxygen, alkalinity, ammonia, nitrate, phosphate, total phosphorus and chlorophyll-a. Measurement and analysis of water quality parameters are referred to APHA (1981).

The fertility rate (trophic state) of waters was analyzed by calculating the value of the trophic state index (TSI) according to Carlson (1977) as quoted in the guidebook published by Kementerian Lingkungan Hidup (2008), with a series of formula as follow:

TSI $=($ TSI-SD ++ TSI TSI-TP-Chl $) / 3$ where:

TSI = Carlson's Trophic State Index

TSI-SD = Trophic State Index for Secchi Disk Depth

TSI-TP = Trophic State Index for Total Phosphorus

TSI-Chl = Trophic State Index for chlorophyll-a

TSI-SD $=60-14.41 *$ Ln [SD], where SD = Secchi Disk in meters

TSI-TP $=4.15+14.42{ }^{*} \operatorname{Ln}[\mathrm{TP}]$, where TP $=$ total phosphorus in $\mu \mathrm{g} / \mathrm{liter}$

TSI-Chl $=30.6+9.81^{*} \mathrm{Ln}[\mathrm{Chl}]$, where $\mathrm{Chl}=$ chlorophyll-a concentration in $\mu \mathrm{g} / \mathrm{liter}$

The conditions of aquatic trophic state index of Carlson are classified into four categories namely: very low, low, medium and high (Table 2).

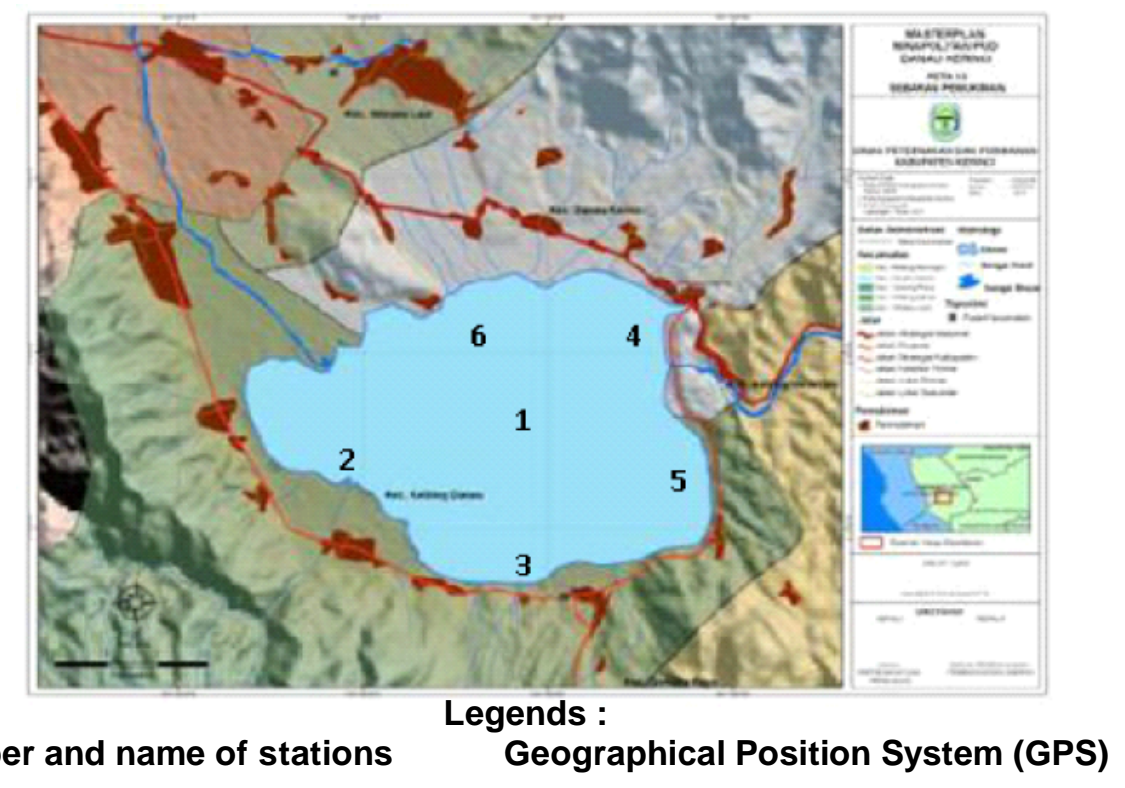

Number and name of stations

$1=$ Middle of the lake

$2=$ Inlet

$3=$ Rice field areas

$4=$ Outlet

$5=$ Protected forest areas

$6=$ Residential areas

$S=02.08 .937$
$S=02.08 .073$
$S=02.09 .911$
$S=02.07 .490$
$S=02.10 .167$
$S=02.07 .057$

$E=101.29 .858$

$E=101.27 .714$

$E=101.28 .308$

$E=101.31 .398$

$E=101.31 .593$

$E=101.30 .457$

Figure 1. Research stations in Kerinci Lake of Jambi, Sumatra. 
Table 1. Physico-chemical and biologycal parameters measured as well as the agent, tools and methods used.

\begin{tabular}{clll}
\hline No & Parameters & Materials and Tools & Methods \\
\hline A & Physical Parameters & Hg-Thermometer & \\
1 & Temperature & Ekman grab & In situ \\
2 & Bottom Substrate & Sechi disk & In situ \\
3 & Water transparancy & Depth Sounder & In situ \\
4 & Water Depth & SCT-meter & In situ \\
5 & Conductivity & In situ \\
B & Chemical Parameters & pH indicator & In situ \\
6 & pH & DO Meter & In situ \\
7 & Dissolved Oxygen & Titrimetic tools & Titrimetri \\
8 & Alkalinity & Spectrophotometer & Phanate \\
9 & Ammonia & Spectrophotometer & Nesler's \\
10 & Nitrate & Spectrophotometer & Vanadate Molybdat \\
11 & Phosphate & Spectrophotometer & Vanada te Molybdat \\
12 & Total Phosphorus & & \\
C & Biologycal Parameters & Spectrophotometer & Calorimetric \\
13 & Chlorophyll-a &
\end{tabular}

Table 2. Trophic state categories based on the Trophic State Index' Carlsons

\begin{tabular}{lll}
\hline Score & Trophic State & \\
\hline$<30$ & Ultraoligotrophic & $\begin{array}{l}\text { The water is crystal clear, high dissolved oxygen concentrations } \\
\text { throughout the year and reached the hypolimnion zone }\end{array}$ \\
$30-40$ & Oligotrophic & $\begin{array}{l}\text { The water is crystal clear, there may be a restriction on the anoxic } \\
\text { hypolimnetic zone periodically }\end{array}$ \\
$40-50$ & Mesotrophic & $\begin{array}{l}\text { Water transparency is medium, increasing the changing of anoxic } \\
\text { nature in hypolimnetic zone. }\end{array}$ \\
$50-60$ & Light (low) eutrophic & $\begin{array}{l}\text { The decline in water clarity, hypolimnetic zone is anoxic, there is a } \\
\text { problem of water plants, only fish that are able to live in warm } \\
\text { water. }\end{array}$ \\
$70-70$ & $\begin{array}{l}\text { Medium (moderate) } \\
\text { eutrophic }\end{array}$ & $\begin{array}{l}\text { Dominated by blue-green algae, occur clotting, water plant probler } \\
\text { has been extensively }\end{array}$ \\
$>80$ & Heavy (high) & $\begin{array}{l}\text { Heavy algae blooming occurs, water plants form a layer bed like th } \\
\text { hypereutrophic conditions }\end{array}$ \\
\hline
\end{tabular}

Calculating the potential fish production dertermined in $\mathrm{kg} / \mathrm{ha} / \mathrm{year}$ used the formula from Moreau \& De Silva (1991), namely:

$\mathrm{Y}=28.2+10.5 \times(\mathrm{Chl}-\mathrm{a})$

where $\mathrm{Y}=$ potential fish production $(\mathrm{kg} / \mathrm{ha} / \mathrm{year})$ and $(\mathrm{Chl}-\mathrm{a})=$ chlorophyll-a concentration in unit of $\mu \mathrm{g} / \mathrm{liter}$.

\section{RESULTS AND DISCUSSION Results}

From the results of soil sampling at the bottom, it turned out that the bottom substrate of Kerinci Lake in six research stations was dominated by sandy mud substrate. Based on the temporal distribution of water quality values (Table 3), the water transparency of the 
months from April to October ranged from 1.1 to 1.3 meters (average value of 1.2 meters), the temperature ranged from $22.6-26.7^{\circ} \mathrm{C}$ (average of $25.5^{\circ} \mathrm{C}$ ), conductivity was between $88-93 \mathrm{iS} / \mathrm{cm}$ (average of 91 is $/ \mathrm{cm}$ ), the $\mathrm{pH}$ ranged from 7.1 to 8.2 (average of 7.5 ). Dissolved oxygen content ranged from 6.34 to 7.78 $\mathrm{mg} / \mathrm{L}$ (average of $6.82 \mathrm{mg} / \mathrm{L}$ ), the alkalinity of 33-64 $\mathrm{mg} / \mathrm{L}$ (average of $54 \mathrm{mg} / \mathrm{L}$ ), ammonia levels from 0.06 to $0.23 \mathrm{mg} / \mathrm{L}$ (average of $0.11 \mathrm{mg} / \mathrm{L}$ ), nitrate $25-122$ $\mu \mathrm{g} / \mathrm{L}$ (average of $81 \mu \mathrm{g} / \mathrm{L}$ ), phosphate $54-58 \mu \mathrm{g} / \mathrm{L}$ (an average of $56 \mu \mathrm{g} / \mathrm{L}$ ), total phosphorus ranged from 66 $78 \mu \mathrm{g} / \mathrm{L}$ (average of $72 \mu \mathrm{g} / \mathrm{L}$ ) and chlorophyll-a ranged from $18-35 \mu \mathrm{g} / \mathrm{L}$ (average of $27 \mu \mathrm{g} / \mathrm{L}$ ).

Table 3. Mean Water quality values of Lake Kerinci based on the temporal distribution

\begin{tabular}{llllllll}
\hline Parameters & Units & April & June & August & October & Mean & Std \\
\hline Transparency & meter & 1.1 & 1.3 & 1.2 & 1.2 & 1.2 & 0.1 \\
Temperature & ${ }^{\circ} \mathrm{C}$ & 26.7 & 26.2 & 22.6 & 26.3 & 25.5 & 1.9 \\
Conductivity & $\mu \mathrm{S} / \mathrm{cm}$ & 90 & 92 & 93 & 88 & 91 & 2 \\
$\mathrm{PH}$ & $\mathrm{unit}$ & 8.2 & 7.1 & 7.3 & 7.3 & 7.5 & 0.5 \\
Oxygen & $\mathrm{mg} / \mathrm{L}$ & 7.78 & 6.42 & 6.34 & 6.72 & 6.82 & 0.66 \\
Alkalinity & $\mathrm{mg} / \mathrm{L}$ & 64 & 33 & 62 & 55 & 54 & 14 \\
Ammonia & $\mathrm{mg} / \mathrm{L}$ & 0.06 & 0.23 & 0.08 & 0.09 & 0.11 & 0.08 \\
Nitrate & $\mu \mathrm{g} / \mathrm{L}$ & 25 & 104 & 122 & 74 & 81 & 42 \\
Phosphate & $\mu \mathrm{g} / \mathrm{L}$ & 54 & 55 & 58 & 56 & 56 & 2 \\
Total-P & $\mu \mathrm{g} / \mathrm{L}$ & 68 & 66 & 78 & 74 & 72 & 6 \\
Chlorophyll-a & $\mu \mathrm{g} / \mathrm{L}$ & 35 & 31 & 22 & 18 & 27 & 8 \\
\hline
\end{tabular}

Based on the spatial distribution (Table 4), the water transparency from station 1 to 6 , ranged from 1.1 to 1.3 meters (average value of 1.2 meters), the temperature ranged from $25.6-27.0^{\circ} \mathrm{C}$ (average of $26.2^{\circ} \mathrm{C}$ ), conductivity was between $87-90 \mathrm{iS} / \mathrm{cm}$ (average of $88 \mathrm{iS} / \mathrm{cm}$ ), the $\mathrm{pH}$ ranged from 7.6 to 7.7 (average of 7.6). Dissolved oxygen content ranged from 7.66 to $8.29 \mathrm{mg} / \mathrm{L}$ (average of $7.89 \mathrm{mg} / \mathrm{L}$ ), the alkalinity of $53-55 \mathrm{mg} / \mathrm{L}$ (average of $54 \mathrm{mg} / \mathrm{L}$ ), ammonia levels from 0.07 to $0.12 \mathrm{mg} / \mathrm{L}$ (average of $0.11 \mathrm{mg} / \mathrm{L}$ ), nitrate $41-133 \mu \mathrm{g} / \mathrm{L}$ (average of $65 \mu \mathrm{g} / \mathrm{L}$ ), phosphate $46-66 \mu \mathrm{g} / \mathrm{L}$ (an average of $55 \mu \mathrm{g} / \mathrm{L}$ ), total phosphorus ranged from $62-79 \mu \mathrm{g} / \mathrm{L}$ (average of $70 \mu \mathrm{g} / \mathrm{L}$ ) and chlorophyll-a ranged from $22-33 \mu \mathrm{g} / \mathrm{L}$ (average of 26 $\mu \mathrm{g} / \mathrm{L})$.

Table 4. Mean water quality values of Lake Kerinci based on the spatial distribution

\begin{tabular}{lcccccccc}
\hline Parameters & Units & St-1 & St-2 & St-3 & St-4 & St-5 & St-6 & Mean \\
\hline Transparency & meter & 1.2 & 1.1 & 1.3 & 1.2 & 1.3 & 1.2 & 1.2 \\
Temperature & ${ }^{\circ} \mathrm{C}$ & 25.7 & 25.8 & 27.0 & 25.7 & 26.2 & 26.5 & 26.2 \\
Conductivity & $\mu \mathrm{S} / \mathrm{cm}$ & 87 & 90 & 88 & 88 & 89 & 88 & 88 \\
$\mathrm{PH}$ & $\mathrm{unit}$ & 7.6 & 7.6 & 7.6 & 7.6 & 7.7 & 7.6 & 7.6 \\
Oxygen & $\mathrm{mg} / \mathrm{L}$ & 7.66 & 8.29 & 7.76 & 7.88 & 8.12 & 7.67 & 7.89 \\
Alkalinity & $\mathrm{mg} / \mathrm{L}$ & 54 & 55 & 53 & 55 & 53 & 54 & 54 \\
Ammonia & $\mathrm{mg} / \mathrm{L}$ & 0.10 & 0.12 & 0.12 & 0.12 & 0.12 & 0.07 & 0.11 \\
Nitrate & $\mu \mathrm{g} / \mathrm{L}$ & 52 & 133 & 72 & 52 & 42 & 41 & 65 \\
Phosphate & $\mu \mathrm{g} / \mathrm{L}$ & 59 & 66 & 51 & 59 & 46 & 47 & 55 \\
Total-P & $\mu \mathrm{g} / \mathrm{L}$ & 75 & 79 & 65 & 73 & 62 & 65 & 70 \\
Chlorophyll-a & $\mu \mathrm{g} / \mathrm{L}$ & 33 & 30 & 23 & 22 & 28 & 22 & 26 \\
\hline
\end{tabular}

Remark: St $=$ Station $;$ Std $=$ Standard Deviation

In the deepest part between 0-70 meters (station 1), water temperature ranged between $23.1-25.5^{\circ} \mathrm{C}$ and average $23.8^{\circ} \mathrm{C}$, conductivity of $87-110 \mathrm{iS} / \mathrm{cm}$ with an average of $98 \mathrm{iS} / \mathrm{cm}$, pH waters of 6.86-7.64 with an average of 7.24 and dissolved oxygen levels ranging from 1.39 to $7.66 \mathrm{mg} / \mathrm{L}$ with an average of $4.01 \mathrm{mg} / \mathrm{L}$.
The vertical profile of the four parameters can be seen in Figure 2.

Trophic state index values of the lake waters based on the temporal and spatial distributions were listed in Table 5 and 6 , while the potential of fish production were listed in Table 7 and 8. 


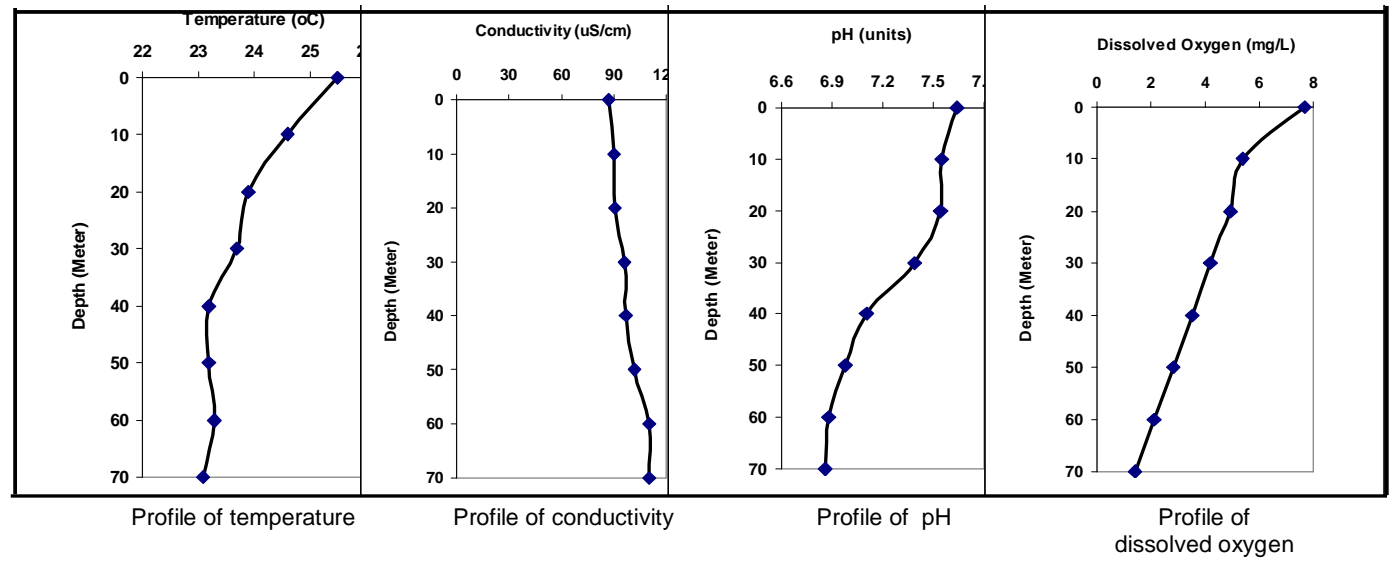

Figure 2. Vertical profiles of temperature, conductivity, $\mathrm{pH}$ and oxygen in Lake Kerinci.

Table 5. Trophic state index (TSI) of Kerinci Lake based on the temporal distribution

\begin{tabular}{llcl}
\hline No & Months of Research & Score of TSI & Trophic State \\
\hline 1 & April & 62.86 & Moderate eutrophic \\
2 & June & 61.59 & Moderate eutrophic \\
3 & August & 61.73 & Moderate eutrophic \\
4 & October & 60.81 & Moderate eutrophic \\
\hline & Average & 61.75 & Moderate eutrophic \\
\hline
\end{tabular}

Table 6. Trophic state index (TSI) of Kerinci Lake based on the spatial distribution

\begin{tabular}{llcl}
\hline No & Stations of Research & Score of TSI & Trophic State \\
\hline 1 & Station-1 & 62.72 & Moderate eutrophic \\
2 & Station-2 & 63.01 & Moderate eutrophic \\
3 & Station-3 & 61.13 & Moderate eutrophic \\
4 & Station-4 & 61.96 & Moderate eutrophic \\
5 & Station-5 & 60.81 & Moderate eutrophic \\
6 & Station-6 & 60.86 & Moderate eutrophic \\
\hline & Average & 61.75 & Moderate eutrophic \\
\hline
\end{tabular}

Table 7. Potential of fish production in the Lake Kerinci based on the temporal distribution

Months of Research

Potential fish production

\begin{tabular}{lcc}
\cline { 2 - 3 } & $\mathbf{( k g / h a / y e a r )}$ & (ton/year) \\
\hline April & 392 & 1,647 \\
June & 356 & 1,493 \\
August & 259 & 1,089 \\
October & 219 & 920 \\
\hline Average & 307 & 1,287 \\
\hline
\end{tabular}


Table 8. Potential of fish production in the Lake Kerinci based on the spatial distribution

\begin{tabular}{lcc}
\hline & & Potential fish production \\
\cline { 2 - 3 } Stations of Research & (kg/ha/year) & (ton/year) \\
\hline Station-1 & 367 & 1,541 \\
Station-2 & 341 & 1,430 \\
Station-3 & 288 & 1,210 \\
Station-4 & 286 & 1,199 \\
Station-5 & 305 & 1,282 \\
Station-6 & 253 & 1,061 \\
\hline Average & 307 & 1,287 \\
\hline
\end{tabular}

\section{Discussion}

Limnological Condition

The water condition of Lake Kerinci, based on the value of each parameter did not seen to much vary, either measured by the time of sampling/ temporal ways (April to October) or measured by sampling stations/ spatial ways (station 1 to 6). Jorgensen (1980) stated the water condition of the lake with a variation value of water quality parameters does not differ significantly based on the time and place, is alleged that the limnological condition of the lake waters was relatively stable.

Aquatic trophic conditions in terms of water transparency parameters either measured by the temporal or spatial ways ranged from 1.1-1.3 meters with an average of 1.2 meters indicate the lake waters are included in the meso-eutrophic (Golman \& Horne, 1983; Jorgensen, 1980; Cooke et al., 2005). Water transparency was related to the level of turbidity of river water pouring into the waters of the lake. In addition, the presence of land use activities around the lake (rice fields and settlements) allows the inclusion of organic colloidal particles into the waters of the lake which caused high turbidity levels, this occurred when the wet season had come (Davis \& Cornwell, 1991).

In the deepest part, the water temperature shows a decreasing value with increasing water depth but decreasing of the value was very little. The small difference between surface and bottom water temperatures indicates that Lake Kerinci is classified as an oligomictic lake. This kind of lake in the tropical region has rarely perfect water circulation (Whitten et al., 1987). The type of the lake mentioned above usually do not have a stratification layer of epilimnion, metalimnion and hypolimnion. Pescod (1973) stated that the water temperature changed suddenly and reached of $2.8^{\circ} \mathrm{C}$ could destroy fish. Ahmad (1992) stated that the optimal water temperature for fish life occurs from 28 to $30^{\circ} \mathrm{C}$, under a temperature of $25^{\circ} \mathrm{C}$ to $18^{\circ} \mathrm{C}$, certain fish species still survive but his appetite begin to decline. Based on the references, the water temperature of Lake Kerinci seems be ideal to support fish life.

The profile of $\mathrm{pH}$ and dissolved oxygen content tends to decrease with increasing the depth, while the value of the conductivity rose with increasing the depth that described the number of colloidal particles containing ions in the bottom waters (Wetzel, 1975; Boyd, 1979). The level of oxygen in the bottom waters of $1.39 \mathrm{mg} / \mathrm{L}$ is not suitable for fish life (Kartamihardja et al., 1987). The $\mathrm{pH}$ of water decreasing from 7.64 at the surface to 6.86 at the bottom may influence the organic matter in the bottom waters (Boyd, 1979). Organic materials stacked in the bottom of the lake are decomposed by anaerobic bacteria and potentially decrease the dissolved oxygen content in the water so that oxygen levels become low. Due to low dissolved oxygen content in the bottom waters of Kerinci Lake, the bottom organism's life is limited. This is seen from the few bottom fish caught by fishermen (Samuel et al., 2013).

According to Pescod (1973), dissolved oxygen in the water at least $2 \mathrm{mg} / \mathrm{L}$ is sufficient to support fish life normally, but there are no toxic substances (toxic) in the waters. Based on the Indonesian Government Regulation No. 82/2001, the water quality standards which intend to sustain the life of aquatic organisms with reference to the dissolved oxygen levels are as follows: oxygen levels above $6 \mathrm{mg} / \mathrm{L}$ is very good (grade I), between 4-6 mg/L belonging to grade II. Dissolved oxygen content of Kerinci Lake waters is clustered in criteria of grade I and II, while below the layer the oxygen levels are started to decline. However, when viewed from the levels of dissolved oxygen, the waters 
of Kerinci Lake are still worth to supporting fish life, especially the kinds of pelagic fish. Based on the water quality criteria proposed by Jeffries \& Mills (1996), the levels of dissolved oxygen in the water ranged from 4.5 to $6.4 \mathrm{mg} / \mathrm{L}$, so that the water quality status of Kerinci Lake would be lightly polluted waters. A part of them, the oxygen level values are still below 4 $\mathrm{mg} / \mathrm{L}$, this concludes that the waters of Kerinci Lake could be classified into mild-moderate polluted waters.

The $\mathrm{pH}$ of the waters during sampling (April to October) ranging from 7.1 to 8.2 with an average of 7.5 and based on the location of research, it was ranging from 7.6 to 7.7 with an average of 7.6 characterized the waters of Kerinci Lake as alkaline. Pescod (1973) mentionned the tolerance limit of aquatic organisms on the $\mathrm{pH}$ is various and influenced by many factors such as temperature, dissolved oxygen and alkalinity. In order to support fish life reasonably it is needed the waters with a $\mathrm{pH}$ ranging from 5.0 to 9.0 (Novotny \& Olem, 1994). Tebbut (1992) stated that the ideal waters condition for supporting fish life is at $\mathrm{pH}$ of 7.0 to 8.5. From that information it could be mentionned the waters of Lake Kerinci could be classified as ideal waters to support fish life.

The value of water alkalinity could indicate the buffer capacity of the waters and could be used to estimate trophic state of waters (Swingle, 1968). Temporal and spatial measurements, alkalinity values of waters ranged from 33-64 mg/L CaCO 3 eq. with an average of $54 \mathrm{mg} / \mathrm{L} \mathrm{CaCO}_{3}$ eq and $53-55 \mathrm{mg} / \mathrm{L} \mathrm{CaCO}_{3}$ eq. with an average of $54 \mathrm{mg} / \mathrm{L} \mathrm{CaCO}_{3}$ eq. Relationship between the alkalinity and the water quality for fishery purposes, the waters of Kerinci Lake is classified as waters with meso-eutrophic because its value is below the range of values between 100-250 mg/liter $\mathrm{CaCO}_{3}$ eq. (Canter \& Hill, 1979).

Conductivity value provided an overview about the amounts of dissolved salt content or ionized in a body of water. Both APHA (1981) and Boyd (1979) mentionned that the tolerance limits of the conductivity value of fish are affected by the water hardness. For a proper life, the fish could tolerate conductivity ranging in value of 150-500 $\mu \mathrm{mhos} / \mathrm{cm}$ (Sylvester, 1978). The results of measuring the conductivity in the waters of Lake Kerinci, conductivity average value was 91 ìs/ $\mathrm{cm}$ (temporal measurement), $88 \mathrm{iS} / \mathrm{cm}$ (spatial measurement), and the vertical measurement, the value was an average of $98 \mathrm{iS} / \mathrm{cm}$. The average conductivity value shows a relatively good value for the fish life (Kartamihardja et al., 1987). When the conductivity value is compared with that of Batur Lake of Bali where the conductivity value of above 2,500 ìmhos/cm (Samuel et al., 2011), it indicates that the waters of Kerinci Lake have low mineral salts content.

Phosphate content ranged between 54-58 $\mu \mathrm{g} / \mathrm{L}$ with an average of $56 \mu \mathrm{g} / \mathrm{L}$ and total phosphorus between $68-78 \mu \mathrm{g} / \mathrm{L}$ with an average of $72 \mu \mathrm{g} / \mathrm{L}$. The measurement based on the locations of research station (Spatial distribution), mean value of phosphate and total phosphorus were $55 \mu \mathrm{g} / \mathrm{L}$ and $70 \mu \mathrm{g} / \mathrm{L}$ respectively, classified the Kerinci Lake into criteria as fertile waters/ eutrophic level (Liaw, 1969). The concentration of phosphate in natural waters rarely exceeds to $100 \mu \mathrm{g} / \mathrm{L}$, except for waters that receive domestic wastes, industrial waste and runoff from agricultural areas/estates that charge with phosphate fertilization (Wardoyo, 1979). Jorgensen (1980) and Alabaster \& Llyoid (1981) also mentioned that The level of total phosphorus (TP) ranging between 66-78 $\mu \mathrm{g} / \mathrm{L}$ (temporal distribution) and 62-79 $\mu \mathrm{g} / \mathrm{L}$ (spatial distribution), is classified as moderate to high fertility rates characterizing the eutrophic waters.

Ammonia content of waters ranged from 0.06 to $0.23 \mathrm{mg} / \mathrm{L}$ with an average of $0.11 \mathrm{mg} / \mathrm{L}$. The ammonia content values measured by temporal was not significant difference with spatial that ranged from 0.07-0.12 mg/L (average of $0.11 \mathrm{mg} / \mathrm{L}$ ). Pescod (1973) stated that the capacity of ammonia toxicity increased with increasing the $\mathrm{pH}$ and decreased when the $\mathrm{pH}$ dropped. Further said for the waters in the tropical regions, ammonia in waters was not more than 1.0 $\mathrm{mg} / \mathrm{L}$. According to Redner (1978) as cited in Arthana \& Restu (2009), the fish, Tilapia aurea, is relatively sensitive to ammonia in which the ammonia concentration of $0.12 \mathrm{mg} / \mathrm{L}$, its growth has been affected and if referring to Government Regulation No. 82, 2001 on the control of water pollution, free ammonia levels in the water were advised not to be more than $0.02 \mathrm{mg} / \mathrm{L}$. From these criteria, the condition of the Kerinci Lake is categoried as a high ammonia level. It is estimated by the decomposition process of organic material in the bottom part of the lake where is among excreted ammonia into the water system. Besides that, domestic and agricultural wastes (remnants of fertilizer into the waters widely available on the lake are also potential to produce the compounds of ammonia, nitrate and nitrite through chemical reactions in the process of nitrification.

Nitrate levels temporally ranged from 25 to 122 $\mu \mathrm{g} / \mathrm{L}$ with an average of $81 \mu \mathrm{g} / \mathrm{L}$. Spatially, it ranged from $41-133 \mu \mathrm{g} / \mathrm{L}$ with an average of $65 \mu \mathrm{g} / \mathrm{L}$. Referring to the criteria of the water fertility proposed by Wetzel (1975), based on those values the waters condition of Kerinci Lake is classified as moderate fertility (meso- 
eutrophic). The mean levels of chlorophyll-a in Lake Kerinci waters was $27 \mu \mathrm{g} / \mathrm{L}$ (temporal distribution) and $26 \mu \mathrm{g} / \mathrm{L}$ (spatial distribution), classified the waters as eutrophic level (Jorgensen, 1980).

The average trophic state index of waters temporally ranged from 60.81 to 62.86 and spatially ranged from 60.81 to 63.01 . Both temporal and spatial ways have the same average value of 61.75 with moderate eutrophic state. The eutrophic state characterized Kerinci Lake as a high fertility rate. The high fertility of the lake waters is suspected due to the high concentration of phosphorus. The process of the high water fertility in Lake Kerinci can be explained as follows: 1) the nutrients derived from agricultural activities/plantation around the catchment area of the lake that its waste entering through the inlets to the lake waters; 2) materials coming from residential areas and human activities around the lake which stimulante the waters fertility of the lake; and 3) materials derived from feed waste released into the waters of the floating net cage activity which were found around the lake.

\section{Potential Fish Production}

The potential fish production in Lake Kerinci temporally ranged between $219-392 \mathrm{~kg} / \mathrm{ha} /$ year with an average of $307 \mathrm{~kg} / \mathrm{ha} /$ year. Based on spatial distribution, the potential fish production ranged from $253-367 \mathrm{~kg} / \mathrm{ha} /$ year with an average of $307 \mathrm{~kg} / \mathrm{ha} /$ year. With this average, the lake was classified as the waters having a high potential fish production (Kartamihardja, 1987). The high potential fish production in Kerinci Lake is probably due to closely relationship to the trophic state of waters that is also in a high fertility rate.

Taking account of the water area wide of Kerinci Lake that is around of 4,200 ha, so the potential fish production was calculated at average value of 1,287 tons/year. Jusuf (2009) summaried that the number of potential fish production for all lakes in Indonesia amounted to $\pm 158,162$ tons/year. Based on this reference, it is found that the number of potential fish production of Kerinci Lake exceeded $\pm 0.82 \%$. From the fishery statistical data of Kerinci District in 2012, the production of fish caught in Lake Kerinci was reported about 957.81 tons (Gazam, 2013). This indicates that the fishing in the lake would be still below the number of estimated potential production (average of 1,287 tons/year). Referring to the sustainable utilization of fish resources, it suggests that the activities of fisheries in Lake Kerinci would be maintained with a production target to be not exceeded the value of the potential fish production of Kerinci Lake.

\section{CONCLUSION}

The aquatic trophic state index (TSI) value calculated from the values of water quality parameters (water transparency, total phosphorus and chlorophylla) either measured by temporal or spatial ways has TSI with an average of 61.75 , indicating the classification of the waters of Lake Kerinci is in eutrophic level. Based on the analysis of some parameter values (conductivity, the concentration of phosphate $\left(\mathrm{PO}_{4}-\mathrm{P}\right)$, nitrate $\left(\mathrm{NO}_{3}-\mathrm{N}\right)$, and alkalinity), temporally and spatially, the lake waters are generally categorized as productive waters that might support the life of aquatic organisms. This condition estimate the potential fish production of $307 \mathrm{~kg} / \mathrm{ha} /$ year. Taking into account the broad waters of the lake, potential of fish production was an average of 1,287 tons/year. This potential fish production value was relatively higher than that repoted in 2012 production which amounted to 957.81 tons. In order to maintain the sustainability of fish resources in Lake Kerinci, it suggests that fish production should not exceed the value of the potency of production as obtained in this study.

\section{ACKNOWLEDGEMENTS}

This paper is a part of contribution in research on "Bioecology and stock assessment of fish resources in Lake Kerinci, Jambi in 2013 under the Research Institute for Inland Fisheries, Palembang. The authors would like to express their appreciations to the Head and Researcher of The Research Institute for their valuable advice and comments, and also to the local fishermen for their helpful participations.

\section{REFERENCES}

Ahmad, T. 1992. Pengelolaan mutu air untuk budidaya ikan (The management of water quality for fish farming). Balai Penelitian Perikanan Budidaya Pantai. Badan litbang Pertanian, Departemen Pertanian (Research Institute for Coastal Aquaculture. Agricultural $R$ \& D Agency, Department of Agriculture), Jakarta. $41 \mathrm{pp}$.

Alabaster, J.S \& R. Llyoid. 1981. Water Quality Criteria for Freshwater Fish. Second Edition. FAOUnited Nation, Butterwoth. 361 pp.

APHA. 1981. Standart Method for the Examination of Water and Wastewater, $15^{\text {th }}$ Edition. American Public Health Association, Washington, D.C. 1134 pp.

Arthana, I.W \& I.W. Restu. 2009. Hubungan N/P rasio dengan tingkat eutrofikasi di Danau Batur, 
Bali (Relationship N/P ratio with the rate of eutrophication in Lake Batur Bali). Fakultas Pertanian Universitas Udayana (Faculty of Agriculture, University of Udayana), Denpasar. 50 pp.

Boyd, C.E. 1979. Water Quality in Warmwater Fishponds. Auburn University, Depart. Of Fisheries and Alied Aquaculture. First Edition, Alabama, USA. 359 pp.

Canter, I.W \& I.G. Hill. 1979. Handbook of Variables Environmental Assessment. Ann Arbor Science Publisher, Inc., Michigan. 203 pp.

Cooke, G.D., E.B. Welch, S.A. Peterson \& S.A. Nichols. 2005. Restoration and Management of Lakes and Reservoirs. Third Edition. Taylor \& Francis Group, Boca Rotan, London, New York, Singapore. $591 \mathrm{pp}$.

Davis, M.I \& D.A. Cornwell. 1991. Introduction to Environmental Engineering. Second Edition. McGraw-Hill, Inc. New York. 822 pp.

Gazam, G. 2013. Profil perikanan tangkap di Danau Kerinci, serta keragaan aturan daerah dan kearifan lokal (Profile of fisheries in Lake Kerinci, as well as the performance of local rules and local wisdom). Disampaikan pada Workshop Penyusunan Rencana Pengelolaan Perikanan Tangkap di PUD Danau Kerinci (Presented at the Workshop on Capture Fisheries Management Planning in Inland Waters of Lake Kerinci), Bandung. $10 \mathrm{pp}$.

Golman, C.R \& A.J. Horne. 1983. Limnologi. Int. Student Ed. Mc-Graw Hill Inc. Book Co, Tokyo. $464 \mathrm{pp}$.

Jeffries, M \& D. Mills. 1996. Freshwater Ecology. Principles and Applications, John Wiley and Sons, Chicester United Kingdom.

Jorgensen, S.E. 1980. Lake Management. University of Copenhagen, Denmark. Water Development Supply and Management. Vol. 14, Pergamon Press. Oxford. 167 pp.

Jusuf, G. 2009. Dukungan penelitian untuk pengelolaan perikanan di perairan umum daratan Indonesia bagi kesejahteraan masyarakat (Supporting the research for fisheries management in the Indonesia's inland waters for public welfare). Makalah disampaikan dalam Forum PU Indonesia VI (Paper presented at the Forum of the Indonesia's inland waters VI), Palembang. $19 \mathrm{pp}$.

Kartamihardja, E.S. 1987. Potensi produksi dan pengelolaan perikanan di Danau Toba, Sumatera Utara (Potential of production and fisheries management in Lake Toba, North Sumatra). Bulletin Penelitian Perikanan Darat, Vol.6, No.1, Juni 1987 (Inland Fisheries Research Bulletin, Vol.6, No.1 June 1987), Bogor: p. 65-77.

Kartamihardja, E.S., A.S. Nastiti, Krismono, K. Purnomo \& A. Hardjamulia. 1987. Penelitian limno-biologis Waduk Saguling pada tahap prainundasi (Limno-biological research Saguling on pre-inundation. Bulletin Penelitian Perikanan Darat, Vol.6, No. 3, Desember 1987 (Inland Fisheries Research Bulletin, Vol. 6 No. 3 December 1987), Bogor: 32-62.

Kottelat, M., J.A. Whitten, N. Kartikasari \& S. Wiryoatmojo. 1993. Freshwater Fishes of Western Indonesia and Sulawesi. Periplus Edition and EMDI Project Indonesia, Jakarta. 221 pp.

Kementerian Lingkungan Hidup. 2008. Pedoman Pengelolaan Ekosistem Danau (Guidelines for the Management of Lake Ecosystem). Deputi Bidang Peningkatan Konservasi Sumber Daya Alam dan Pengendalian Kerusakan Lingkungan (Deputy Enhancement of Natural Resources Conservation and Environmental Degradation Control), Jakarta. $118 \mathrm{pp}$.

Kementerian Lingkungan Hidup. 2013. Gerakan Penyelamatan Danau (GERMADAN) Kerinci (Rescue Movement of Lake Kerinci). Deputi Bidang Pengendalian Kerusakan Lingkungan dan Perubahan Iklim (Deputy Environmental Degradation Control and Climate Change), Jakarta. $84 \mathrm{pp}$.

Liaw, W.K. 1969. Chemical and biological studies of fish ponds and reservoirs in Taiwan, Reprinted from Chinese-American Joint Commission on Rural Reconstruction Fish, Series (7): 43 pp.

Moreau, J \& S.S. De Silva. 1991. Predictive fish yield models for lakes and reservoirs of the Philippines, Sri Lanka and Thailand. FAO Fisheries Technical Paper (319). Food and Agriculture Organization of The United Nations, Rome. 42 pp. 
Novotny, V \& H. Olem. 1994. Water Quality, Prevention, Identification and Management of Pollution. V. N. Reinhold, New York. 1053 pp.

Pescod, M. B. 1973. Investigation of Rational Effluent and Stream Standard for Tropical Countries, AIT Bangkok. 59 pp.

Peraturan Pemerintah R.I. Nomor 82 Tahun 2001. Pengelolaan kualitas air dan pengendalian pencemaran air ( The management of water quality and water pollution control). $28 \mathrm{pp}$.

Samuel, Subagdja, N. K. Suryati, V. Adiansyah, D. Arisna, T. Hifni \& Y. P. Pamungkas. 2011. Karakteristik lingkungan, biologi ikan dan potensi pengembangan perikanan di Danau Batur, Bali (Characteristics of the environment, fish biology and fisheries development potential in Lake Batur, Bali). Laporan Penelitian. Balai Penelitian Perikanan Perairan Umum (Research Report. Research Institute for Inland Fisheries), Palembang. 109 pp.

Samuel, N.K. Suryati, V. Adiansyah, Y.P. Pamungkas \& B. Irawan. 2013. Bioekologi dan kajian stok ikan di Danau Kerinci, Jambi (Bioecology and fish stock assessment in Lake Kerinci, Jambi). Research
Report. Research Institute for Inland Fisheries, Palembang. 89 pp.

Swingle, H.H. 1968. Standardization of chemical analysis for waters and pond muds. FAO Fisheries Report. 44 (4): p. 397-406.

Sylvester, R.O. 1978. Water Quality Studies in the Columbia River Basin. US Departement Interior, Washington DC. 133 pp.

Tebbut, T.H.Y. 1992. Principles of Water Quality Control. Fourth Edition. Pergamon Press, Oxford. $251 \mathrm{pp}$.

Wardoyo, S.T.H. 1979. Kriteria kualitas air untuk keperluan pertanian dan perikanan (The water quality criteria for the purposes of agriculture and fisheries). Pusat Studi Pengelolaan Sumberdaya dan Lingkungan, IPB (Center Resource Management and Environmental Studies, IPB), Bogor. $41 \mathrm{pp}$.

Wetzel, R.G. 1975. Limnology. Saunders College Publishing, Philadelphia. 743 pp.

Whitten, A.J., M. Mustafa \& G.S. Henderson. 1987. Ekologi Sulawesi. Yogyakarta. Universitas Gajah Mada. Hal 708-719. 